\author{
Krzysztof Cieślikowski \\ https://orcid.org/0000-0002-9249-6335 \\ Akademia Wychowania Fizycznego im. Jerzego Kukuczki w Katowicach \\ Wydział Zarządzania Sportem i Turystyką \\ k.cieslikowski@awf.katowice.pl \\ Andrius Brusokas \\ https://orcid.org/0000-0001-8913-1274 \\ Kolegium Kowieńskie / Uniwersytet Nauk Stosowanych \\ Wydział Turystyki i Zarządzania Czasem Wolnym \\ Katedra Biznesu \\ andrius.brusokas@go.kauko.lt
}

\title{
WYBRANE CZYNNIKI ATRAKCYJNOŚCI KONFERENCJI NAUKOWYCH JAKO PRODUKTÓW SYSTEMOWYCH NA MIĘDZYNARODOWYM RYNKU TURYSTYCZNYM
}

\begin{abstract}
Abstrakt: W pracy wskazano wybrane determinanty atrakcyjności międzynarodowych konferencji naukowych jako produktów systemowych na współczesnym międzynarodowym rynku turystycznym, zwłaszcza na rynku turystyki biznesowej. Aby osiągnąć ten cel, zastosowano następujące metody: analizę literatury przedmiotu i raportów, syntezę oraz pasywną i aktywną obserwację. Wykorzystano również bezpośrednią metodę ankietowa, w której posłużono się kwestionariuszem badawczym na stronie internetowej, i skierowano ją do delegatów podczas konferencji Erasmus+ International Week w Kownie. Wskazano kilka najważniejszych warunków atrakcyjności konferencji dla uczestników, które odnoszą się do dostępności transportu i informacji, a także oryginalności miejsca docelowego i programu rekreacyjnego dla delegatów. Współczesne międzynarodowe konferencje naukowe, trwające kilka dni, są systemowymi, wielordzeniowymi produktami turystycznymi. Artykuł jest empiryczny, ale przedstawia także koncepcje rozwoju spotkań konferencyjnych jako atrakcyjnych produktów systemowych we współczesnej gospodarce Unii Europejskiej.
\end{abstract}

Słowa kluczowe: produkt turystyczny, produkt systemowy, przemysł spotkań, konferencja międzynarodowa.

\section{WSTEP}

Globalny rynek turystyczny wciąż się rozwija (WTTC, 2018), dotyczy to również turystyki biznesowej, jako bardzo ważnej część turystyki (związanej z podróżowaniem na spotkania grupowe organizowane poza miejscem stałego pobytu uczestników). Wynika to z potrzeb organizatorów i aktywności zawodowej odwiedzających. Rozwój produktów oferowanych na rynku turystyki biznesowej powinien być efektem akceptacji i uznania potrzeb uczestników spotkań biznesowych (Malekmohammadi, Mohamed, Ekiz, 2011; Breiter, Milman, 2006), co może przyczynić się do lepszego zarządzania produktami, większej satysfakcji odwiedzających i wzrostu wydatków delegatów w miejscu docelowym.

Celem artykułu jest identyfikacja czynników determinujących atrakcyjność międzynarodowych konferencji naukowych jako produktów systemowych na rynku turystycznym na przykładzie konferencji naukowej Erasmus+ International Week (w skrócie: EIW). Aby osiągnać tak sformułowany cel pracy, oprócz badania bezpośredniego zastosowano również metody analizy literatury przedmiotu i raportów, a także obserwacji pasywnych i aktywnych. Autorzy przygotowali kilka pytań w kwestionariuszu znajdującym się na stronie internetowej Survio.com i skierowali je do uczestników międzynarodowej konferencji. Główne kryteria zwykle stosowane przez delegatów przy wyborze spotkań konferencyjnych zostały wybrane po dokonaniu przeglądu literatury przedmiotu. Najważniejsze determinanty atrakcyjnej konferencji związane są z różnymi rodzajami transportu i aktualną dostępnością 
informacji, a także oryginalnością miejsca docelowego i programem rekreacyjnym.

Współczesne międzynarodowe konferencje, zwłaszcza naukowe, są jak systemowe, wielordzeniowe produkty turystyczne (Niemczyk, 2014; Żabiński, 2012). Istnieje kilka czynników determinujących ich atrakcyjność turystyczna, które w wyniku własnych badań autorów zostały zidentyfikowane i uznane za czynniki sukcesu takich produktów systemowych. Do analizy wybrano konferencję naukową Erasmus+ International Week (EIW) w Kownie na Litwie i w 2018 r. przeprowadzono bezpośrednie badanie jej uczestników. Autorzy są świadomi ograniczeń tych badań, ponieważ organizatorzy i menedżerowie turystyki biznesowej w miejscach docelowych (zarówno firmy, jak i administracja lokalna) mogą wykorzystać czynniki sukcesu konferencji opisane w artykule, aby poprawić wyniki wydarzeń biznesowych.

\section{KONFERENCJE MIĘDZYNARODOWE JAKO PRODUKTY SYSTEMOWE NA RYNKU TURYSTYCZNYM}

Turystyka jest zjawiskiem społecznym, kulturowym i gospodarczym, pociagającym za sobą przemieszczanie się ludzi do krajów lub miejsc poza ich zwykłym otoczeniem w celach osobistych lub biznesowych/zawodowych. Są to czynności wykonywane przez odwiedzającego (UN WTO, 2010). Istnieją różne formy turystyki, wyodrębnione według wielu kryteriów. Biorąc pod uwagę główny cel (przyczynę) podróży, sposoby finansowania oraz aktywność zawodowa, można wyróżnić turystykę rekreacyjną (czasu wolnego) i turystykę biznesową (czasu podróży służbowych).

Turystyka biznesowa wiąże się z osobami podróżującymi w celach biznesowych i jest opisywana skrótem MICE: meetings, incentives, conventions, exhibitions (Dwyer, Forsyth, 1997). Synonimem tego terminu jest też określenie „,branża spotkań” (UN WTO, 2010). Jednocześnie termin „podróże służbowe” może odnosić się do wyjazdów na spotkania dwuosobowe (tak zwane spotkania twarzą w twarz), a także do różnych form spotkań grupowych. Termin "turystyka biznesowa” dotyczy przede wszystkim podróży na spotkania grupowe (Davidson, Cope, 2003). UN WTO (2014) - dla celów statystycznych - określa, że spotkania grupowe zaliczane do turystyki biznesowej muszą obejmować co najmniej 10 uczestników i trwać 4 godziny lub dłużej w wynajętej sali (poza siedzibą firmy). Podmioty zajmujące się planowaniem i realizacją tego rodzaju spotkań znajdują się po stronie podaży rynku turystyki biznesowej, podczas gdy nabywcy instytucjonalni oraz delegaci, lub szerzej - uczestnicy, są po stronie popytu rynku spotkań (Cieślikowski, 2014).
Rynek turystyki biznesowej można oddzielić od ogólnego rynku turystyki turystycznej również ze względu na przedmiot transakcji, jakim jest spotkanie biznesowe (wydarzenie biznesowe). Planowanie i realizacja spotkań wymaga współpracy wielu różnych podmiotów świadczących usługi ściśle turystyczne, podmiotów działających na rynkach innych niż turystyka, a także samorządu docelowego miejsca konferencji (Berbeka, Borodako, Niemczyk, Seweryn, 2014; Borodako, Berbeka, Rudnicki, 2014).

Termin „spotkanie konferencyjne” odnosi się do wielu rodzajów spotkań, które różnią się liczbą uczestników, częstotliwością realizacji, lokalizacja metodami finansowania, rodzajem organizatora, czasem realizacji, tematami itp. (Cieślikowski, 2014; Sidorkiewicz, 2014; Swarbrooke, Horner, 2011; Weber, Chon, 2009). Dodanie słowa "międzynarodowy” do nazwy konferencji przywodzi na myśl dużą skalę wydarzenia, większe jego znaczenie, kilka języków konferencji, a przede wszystkim udział osób z zagranicy (Numella, 2017). Konferencje międzynarodowe trwają zwykle kilka dni, a część uczestników pochodzi z zagranicy (ICCA, 2007; UIA, 2018). Wiele badań i raportów pokazuje, że zagraniczni goście takich spotkań generują wyższe wydatki w docelowym mieście niż turyści krajowi (Berbeka, Borodako, Niemczyk, Seweryn, 2014; Nummela, 2017). Ze względu na znaczenie międzynarodowych spotkań konferencyjnych biorący w nich udział są zwykle liderami opinii w swoim środowisku zawodowym i przywiązują dużą wagę do własnego rozwoju oraz do rozwoju organizacji, która delegowała ich na wyjazdy. Niektórzy autorzy podkreślają, że uczestnicy spotkań konferencyjnych korzystają z podstawowych usług turystycznych, ale w czasie wolnym (tj. poza obowiązkowym programem konferencyjnym) zaspokajają takie potrzeby jak turyści przybywający w celach innych niż zawodowe. Podobieństwo dotyczy korzystania z tej samej ogólnej infrastruktury miasta, obiektów kulturalnych i innych atrakcji turystycznych (Swarbrooke, Horner, 2011).

Analizując współczesne międzynarodowe konferencje, traktowane jako produkty przedsiębiorstw i miejsc docelowych, można zauważyć, że konferencje mają wiele cech produktów systemowych. Według Żabińskiego (2012) produktami systemowymi są produkty:

- zaspokajające wszystkie potrzeby i oczekiwania kupujących i rozwiązujące kilka problemów klientów jednocześnie;

- gotowe zaspokoić potrzeby przypisane do więcej niż jednego poziomu potrzeb (według piramidy potrzeb A. Maslowa);

- zazwyczaj charakteryzujące się wysokim stopniem zaawansowania technologicznego;

- ogólnie innowacyjne z punktu widzenia rynku;

- zdolne do samodoskonalenia w zakresie ich wykorzystania lub dalszego rozwoju przedsiębiorstwa; 
- uważane za markowe (tzw. nowe kategorie produktów);

- charakteryzujące się połączeniami sieciowymi (często są tworzone, gdy producent/usługodawca wchodzi w interakcje z sieciami dostawców komponentów lub przedstawicieli handlowych w procesie sprzedaży);

- zachęcające kupującego do nabycia wielu różnych wartości w tym samym czasie, bez konieczności samodzielnego ich komponowania.

Produkty systemowe w turystyce zaspokajają również potrzeby odwiedzających z zagranicy, którzy są zainteresowani różnymi usługami (lokalne podróże, zakwaterowanie, restauracje, usługi czasu wolnego, usługi przewodników itp.). Delegaci w czasie konferencji wydają więcej pieniędzy w miejscu docelowym niż turyści rekreacyjni (EIC, 2018), ale oczekują oni również wysokiej jakości usług wspieranych przez najnowsze rozwiązania technologiczne (Dwyer, Forsyth, Spurr, 2004). Dla organizatorów i miejsc docelowych bardzo ważne jest, aby zarządzający nimi zrozumieli, że spotkania konferencyjne mogą być ich produktami markowymi (Ayaz, Samata, 2017; Cieślikowski, 2015; Malaval, Bénaroya, Digout, Szapiro, 2013; Rogers, Davidson, 2016). Proces planowania i organizowania spotkań konferencyjnych wymaga współpracy wielu podmiotów (Borodako, Kožić, 2016; Crouch, Louviere, 2004). Identyfikacja i pomiar motywacji uczestników (oficjalnych i nieoficjalnych) są bardzo ważne dla atrakcyjności konferencji traktowanej jako produkt na rynku turystycznym.

\section{WYBRANE CZYNNIKI SUKCESU KONFERENCJI NA PRZYKŁADZIE EIW W KOWNIE}

\subsection{METODYKA BADAŃ}

Sukces produktu turystycznego można rozpatrywać z punktu widzenia zaspokojenia potrzeb odwiedzajacych (Lemanowicz, Puciata, 2010) oraz innych podmiotów zaangażowanych $\mathrm{w}$ jego planowanie, realizację i oferowanie (Żemła, 2010). W literaturze istnieje wiele badań określających kryteria wyboru miejsc docelowych (Cieślikowski, 2014; Crouch, Ritchie, 1997; Fenich, 2001; Gugg, Hank-Haase, 1995; Oppermann, 1996). Międzynarodowe spotkania konferencyjne są jednak bardzo zróżnicowanymi produktami systemowymi, które zaspokajają wiele potrzeb różnych grup uczestników (zarówno gości, jak i mieszkańców). Istnieje kilka kryteriów różnicujących te spotkania: czas trwania, miejsce odbywania, rodzaj uczestników, motywy ich uczestnictwa itp.

Sukces takiego produktu turystycznego można rozumieć jako najlepsze zaspokojenie najważniejszych indywidualnych potrzeb. Bardzo ważne wydaje się określenie preferowanych przez delegatów narzędzi i form komunikacji, gdy oczekują oni i szukają informacji o konferencji, preferowanych i wykorzystywanych przez nich środków transportu (po przybyciu na spotkanie) oraz zaspokojenia różnych innych potrzeb w miejscu docelowym (dobre zakwaterowanie, bezpieczeństwo, wycieczki krajoznawcze itp.).

Biorąc pod uwage główne cele przyjazdu, źródła finansowania oraz rodzaj instytucji delegujących uczestników, można wyróżnić międzynarodowe spotkania konferencyjne - spotkania naukowe i kulturalne, na które większość gości przybyła z zagranicy. Przykładem takich spotkań są konferencje typu EIW. EIW to różnorodne konferencje (w tym kilka mniejszych wydarzeń), do których zwykle należą konferencje naukowe, warsztaty i inne wydarzenia oraz wycieczki z ciekawym programem rekreacyjnym (zwiedzanie miejsca docelowego, poznawanie historii miasta, kraju, oglądanie występów kulturalnych itp.). Wdrażają je centra badawcze, uniwersytety i szkoły w krajach Unii Europejskiej (UE) i poza nią (Smith, 2018).

Głównymi celami przyjazdu na konferencje są: poszerzanie wiedzy, wymiana informacji naukowych, nawiązywanie nowych relacji zawodowych itp. Należy zauważyć, że uczestnicy reprezentują różne ośrodki akademickie.

Erasmus+ to program Unii Europejskiej w dziedzinie edukacji, szkoleń i rozwoju sportu na lata 2014-2020. Jego całkowity budżet wynosi 14,7 mld euro. Program skierowany jest zarówno do wykwalifikowanych osób, jak i instytucji. W ramach tego programu uczestnicy mogą również brać udział w wyjazdach studyjnych, a instytucje partnerskie mogą organizować konferencje EIW (ECEC, 2014; Komisja Europejska, 2018).

Przedmiotem badań autorów były czynniki decydujące o atrakcyjności takich konferencji. W badaniach odniesiono się do: różnych form promocji spotkania konferencyjnego, wykorzystanych przez uczestników środków transportu podczas podróży do miejscowości docelowej konferencji, głównych kryteriów wyboru konferencji międzynarodowej, a także oficjalnych i nieoficjalnych motywacji udziału w konferencjach.

W celu realizacji badania wykorzystano źródła wtórne i pierwotne. Analizie poddano konferencje EIW realizowane w latach 2014-2018, koncentrując się na 2017 r. Ponadto dokonano analizy statystycznej danych $\mathrm{z}$ badania ankietowego (z wykorzystaniem kwestionariusza ankiety) uczestników konferencji EIW, która odbyła się w Kownie w dniach 19-23 marca 2018 r.

Przygotowując kwestionariusz ankiety, wykorzystano elementy metody SERVQUAL (Ziethaml, Parasuraman, Berry, 1990). Wybrano również kryteria oceny (cechy) usług konferencyjnych $\mathrm{z}$ istniejących już badań rynkowych i opracowań naukowych dotyczących rynku spotkań konferencyjnych (Oppermann, 1995, 1996). 
W wyniku przeglądu literatury i raportów dotyczących turystyki biznesowej (Zhang, Leung, Qu, 2007; NBTC, 2015) oraz innych wydarzeń, w tym kulturalnych (Ayaz, Samata, 2017) i sportowych (Agha, 2011; Cieślikowski, Brusokas, 2017), przygotowano listę 17 czynników, które według autorów mają znaczący wpływ na wybór miasta, w którym odbywa się konferencja EIW.

Do oceny poziomu oczekiwań uczestników konferencji (poziomu ważności poszczególnych elementów produktu) i spełnienia wymagań uczestników konferencji, zastosowano pięciostopniową skalę Likerta (od 1 do 5) (Pal, Joshi, Kale, Chandel, 2015). W przypadku poziomu ważności 1 oznaczało "mało istotne dla uczestników”, a 5 - „bardzo ważne”; podczas gdy w przypadku spełnienia wymagań: 1 - „bardzo źle spełnione wymaganie” w opinii uczestników, a 5 - „bardzo dobrze spełnione wymaganie". Kwestionariusz został utworzony i otwarty na stronie internetowej Survio.com.

Próbę badawczą stanowili uczestnicy EIW (57 osób). Była to konferencja zorganizowana przez Kauno Kolegija w Kownie. Ankieta została przygotowana tylko dla gości z zagranicy. Łączna liczba uczestników tej konferencji wynosiła 90, a gości zagranicznych było 57. Pochodzili oni z 18 różnych krajów i 29 ośrodków badawczych. Między 1 a 10 maja 2018 r. uczestnicy otrzymali pocztą elektroniczną kwestionariusz online i zostali poproszeni o odpowiedź na zawarte w nim pytania. Odpowiedzi udzieliło 56 osób. Wyniki poddano analizie statystycznej i interpretacji. Autorzy są świadomi zastosowania niewielkiej próby badawczej, ale uważaja, że badania te mogą być pomocne, szczególnie w wyborze kluczowych elementów oceny tego typu spotkania konferencyjnego (międzynarodowa konferencja naukowa) i metodyki badań. Metodykę i wyniki badań można bowiem wykorzystać do ulepszenia produktu systemowego, jakim jest spotkanie konferencyjne, pomagając w ten sposób w osiągnięciu sukcesu rynkowego przez firmy zaangażowane w proces jego przygotowania i wdrożenia.

\subsection{WYNIKI I WNIOSKI}

Łączna liczba konferencji EIW zarejestrowanych w bazie danych staffmobility.eu wynosiła 728 (stan na dzień 30 sierpnia 2018 r.; zob. Staff weeks search, 2018). Analiza informacji zawartych na stronach internetowych organizatorów tego rodzaju konferencji pozwala stwierdzić, że spotkania te są raczej konferencjami naukowymi, z wieloma warsztatami i wydarzeniami kulturalnymi w czasie wolnym. Zwykle uczęszcza na nie od 30 do 90 osób, głównie z zagranicy. Udział w większości EIW jest bezpłatny, a koszty lotu do miasta konferencji i pobytu w hotelu docelowym pokrywane są w całości lub w części ze środków programu Erasmus+.
Respondenci (delegaci na konferencję EIW w Kownie na Litwie) pochodzili z 29 ośrodków badawczych, zlokalizowanych w 18 różnych krajach. Z krajów sąsiadujących z Litwą pochodziło 26\% uczestników badania. Pozostałe kraje europejskie reprezentowało $58 \%$ badanych, a kraje spoza Europy - 16\%. Uczestnicy z Litwy zostali wykluczeni z badania (Litwa to kraj organizatora konferencji).

W ankiecie zapytano uczestników, w jaki sposób dowiedzieli się o wydarzeniu. Większość osób jako źródło informacji wskazała swojego przełożonego - szefa (43\% odpowiedzi), a $29 \%$ badanych - e-mail i znajomych (rys. 1). Należy zaznaczyć, że można było wybrać więcej niż jedną odpowiedź, dlatego odpowiedzi nie sumują się do $100 \%$.

Przedstawiona na rys. 1 struktura wskazuje na silne relacje biznesowe EIW. Z tego powodu komunikacja, promocja i informacje o wydarzeniu powinny być kierowane do decydentów w danej organizacji lub do zainteresowanych stron korzystających z marketingu bezpośredniego i osobistych spotkań.

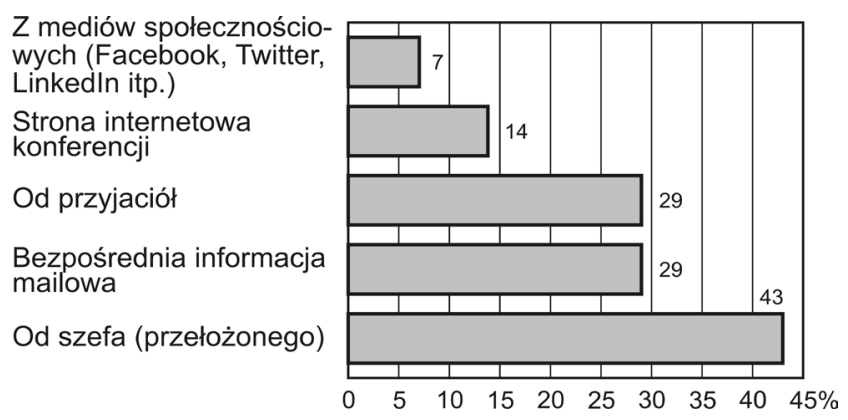

Rysunek 1. Sposoby wyszukiwania informacji na temat EIW przez uczestników konferencji EIW w Kownie Źródło: opracowanie na podstawie badań (Cieślikowski, Brusokas, 2019)

Respondentów zapytano również o główne motywacje uczestnictwa w tym spotkaniu konferencyjnym. Uczestnicy ustalili ważność 11 prawdopodobnych motywów, oceniając czynniki motywujące do udziału w konferencji w skali od 1 do 5 (1 oznaczało „nieważne”, a 5 - „bardzo ważne”). Uzyskane wyniki (tab. 1) pokazują że najważniejszymi motywami uczestnictwa w takim wydarzeniu są: zdobywanie wiedzy (wynik $4,29)$, nowe kontakty zawodowe $(4,21)$ oraz promocja własnej organizacji $(4,00)$.

Kolejne pytanie dotyczyło poziomu spełnienia tych wymagań motywacyjnych przez organizatorów konferencji EIW w Kauno Kolegija w 2018 r. (wymieniono te same wymagania / kryteria oceny; 1 oznacza, że konferencja spełnia kryteria niewystarczająco, 5-że spełnia je całkowicie). Różnica między wynikami średnich dla poszczególnych cech / czynników atrakcyjności (jest to różnica między oczekiwaniami a spełnieniem w opinii delegatów) pozwala analizować atrakcyjność 
Tabela 1. Kluczowe motywacje uczestnictwa w EIW

\begin{tabular}{|r|l|c|}
\hline Lp. & \multicolumn{1}{|c|}{ Czynnik motywacyjny } & $\begin{array}{c}\text { Średnia } \\
\text { ocena }\end{array}$ \\
\hline 1 & Zdobywanie wiedzy & 4,29 \\
\hline 2 & Nowe kontakty zawodowe & 4,21 \\
\hline 3 & Promocja własnej organizacji & 4,00 \\
\hline 4 & Osobiste public relations & 3,86 \\
\hline 5 & Rozwój osobistych kwalifikacji & 3,57 \\
\hline 6 & Popularność uniwersytetu (organizatora) & 3,57 \\
\hline 7 & Spersonalizowany certyfikat uczestnictwa & 3,43 \\
\hline 8 & Możliwość rekreacji w wolnym czasie & 3,36 \\
\hline 9 & Niskie koszty uczestnictwa & 3,14 \\
\hline 10 & Inne, np. karty członkowskie & 2,64 \\
\hline 11 & $\begin{array}{l}\text { Niewielka odległość uczelni, w której organi- } \\
\text { zowana jest konferencja, od hotelu }\end{array}$ & 2,57 \\
\hline
\end{tabular}

Źródło: opracowanie na podstawie badań (Cieślikowski i Brusokas, 2019).

uniwersytetu i miasta, postrzeganą przez zagranicznych delegatów EIW.

Wyniki analizy ankiet pokazuja, że ważne dla delegatów podczas wyboru spotkania konferencyjnego są: „nowość uczelni przyjmującej” (wskaźnik 4,00) i „dostępność informacji o tej konferencji EIW" $(4,00)$. Najmniej istotne dla delegatów były jednak również: „,możliwość dojazdu do miasta samochodem” (2,50), „wiele centrów handlowych", „inne konferencje biznesowe i wydarzenia w tym samym czasie" (te dwie cechy ze średnią oceną 2,43).

Następnie ocenie poddano spełnienie tych wymagań przez organizatorów konferencji EIW w Kownie w skali od 1 do 5, gdzie 1 to „nie jestem w pełni zadowolony”, a 5 - „spełnia bardzo dobrze”. Autorzy obliczyli średnią ocenę dla każdej cechy (tab. 2), przypisali oceny do ważności („wskaźnik ważności”) i spełnienia („,wskaźnik spełnienia”) i porównali spełnienie z oczekiwaniami uczestników (średnia szybkość realizacji została odjęta od średniej oceny oczekiwań). W ten sposób uzyskano wyniki, które wyrażały poziom sukcesu organizatorów spotkania w odniesieniu do indywidualnych kryteriów oceny konferencji przez uczestników.

Prawie wszystkie wymagania uczestników konferencji (czynniki wyboru, determinanty wyboru), które zostały poddane ocenie (tab. 2), spełniły oczekiwania uczestników konferencji (spełnienie tych wymagań przekroczyło oczekiwania / poziom ważności). Jedynie "zróżnicowany program konferencji” $(-0,07)$ i „możliwość odwiedzenia miasta" $(-0,21)$ nieznacznie nie spełniły oczekiwań uczestników. Najważniejsze dla uczestników konferencji EIW przy wyborze tego spotkania konferencyjnego były: „nowość uczelni przyjmującej” (średnia ocena 4,0) i „dostępność informacji o tej konferencji" $(4,0)$. Poziom spełnienia tych wymagań był wyższy, niż oczekiwano przed konferencją.

Tabela 2. Czynniki wpływające na wybór konferencji i ich spełnienie w opinii uczestników EIW w Kownie w 2018 r.

\begin{tabular}{|r|l|c|c|c|}
\hline \multirow{2}{*}{$\mathrm{Nr}$} & \multicolumn{1}{|c|}{ Czynnik wyboru konferencji } & \multicolumn{2}{|c|}{ Ocena } \\
\cline { 3 - 5 } & & $\begin{array}{c}\text { ważności } \\
\text { (oczekiwania) }\end{array}$ & \multirow{2}{*}{ spełnienia } & \multirow{2}{*}{ Wynik } \\
\hline 1 & Nowość uczelni przyjmującej & 4,00 & 4,14 & 0,14 \\
\hline 2 & Dostępność informacji o tej konferencji & 4,00 & 4,14 & 0,14 \\
\hline 3 & Zróżnicowany program konferencji & 3,93 & 3,86 & $-0,07$ \\
\hline 4 & Możliwość zwiedzania miasta, w którym odbywa się konferencja, i okolic & 3,93 & 3,71 & $-0,21$ \\
\hline 5 & Poprzedni kontakt z uczelnią będącą organizatorem konferencji & 3,79 & 4,50 & 0,71 \\
\hline 6 & Nowość kraju, w którym odbywa się konferencja & 3,71 & 4,14 & 0,43 \\
\hline 7 & Nowość miasta, w którym odbywa się konferencja & 3,64 & 4,21 & 0,57 \\
\hline 8 & Podobieństwo wydziałów do tych na moim uniwersytecie & 3,64 & 4,14 & 0,50 \\
\hline 9 & Możliwość dojechania do miasta transportem publicznym & 3,64 & 3,86 & 0,21 \\
\hline 10 & Wiele obiektów kulturalnych w mieście & 3,64 & 4,00 & 0,36 \\
\hline 11 & Zróżnicowana baza gastronomiczna w mieście & 3,21 & 3,86 & 0,64 \\
\hline 12 & Wiele terenów zielonych w mieście & 3,14 & 3,93 & 0,79 \\
\hline 13 & Wiele wydarzeń kulturalnych i sportowych w tym samym czasie w mieście & 3,00 & 3,64 & 0,64 \\
\hline 14 & Urozmaicona baza noclegowa & 3,00 & 3,86 & 0,86 \\
\hline 15 & Możliwość dojazdu do miasta samochodem & 2,50 & 3,00 & 0,50 \\
\hline 16 & Wiele centrów handlowych & 2,43 & 3,86 & 1,43 \\
\hline 17 & Inne konferencje i wydarzenia biznesowe w tym samym czasie & 2,43 & 2,86 & 0,43 \\
\hline
\end{tabular}

Źródło: opracowanie na podstawie: Cieślikowski, Brusokas (2019). 
Najmniej ważne dla uczestników były: „wiele centrów handlowych”, "inne konferencje i wydarzenia biznesowe w tym samym czasie" (oba ze średnią oceną 2,43 ). W przypadku tych wymagań (czynników wyboru, determinant wyboru) poziom spełnienia przekroczył oczekiwania. Uczestnicy EIW byli zaskoczeni dużą liczbą centrów handlowych w mieście (spełnienie przekroczyło oczekiwania o 1,43).

Dokonując ogólnej oceny całego procesu organizacji konferencji EIW w Kownie, należy zauważyć, że uczestnicy byli bardzo zadowoleni z „wcześniejszego kontaktu z tą uczelnią" (średnia ocena spełnienia wymagań w tym zakresie wyniosła 4,5). Uwagę przyciągnęły następujące czynniki: „nowość miasta”, „,nowość kraju”, „nowość uniwersytetu”, a także „podobieństwo wydziałów do tych na moim uniwersytecie", ",dostępność informacji podczas EIW" (dla tych cech średnia ocena spełnienia była wyższa niż 4,0).

\section{DYSKUSJA}

Wyniki badań zaprezentowane w niniejszym artykule umożliwiły wskazanie różnych cech międzynarodowych konferencji typu EIW. Autorzy zidentyfikowali także czynniki warunkujące sukces tego produktu na rynku współczesnej turystyki biznesowej z punktu widzenia uczestników międzynarodowych konferencji naukowych.

Specyfika konferencji EIW przejawia się m.in. w sezonowości ich organizacji (większość z nich realizowana jest głównie w miesiącach wiosennych). W przypadku innych spotkań konferencyjnych badania wskazują jesień i wiosnę jako okresy szczególnego wzrostu liczby tego typu wydarzeń biznesowych. Ponadto konferencje EIW są otwarte dla wszystkich uprawnionych osób, które spełniają kryteria opisane w zasadach programu Erasmus+ (Komisja Europejska, 2018). Główny cel takich spotkań jest związany z działalnością zawodową i naukową uczestników i ich instytucji (uczelni wyższych). Uczestnicy mają dużą swobodę wyboru konferencji, miejscowości docelowych i usług, z których będą korzystać (rodzaj transportu, zakwaterowanie itp.). Finansowanie uczestnictwa pochodzi zarówno ze środków programu Erasmus +, jak i ze środków własnych uczestników. W celu sprawnego procesu komunikacji organizatorów z przyszłymi uczestnikami konieczne jest skupienie się na dotarciu do decydentów na uczelniach partnerskich i przekazywaniu informacji bezpośrednio do nich (np. za pomocą poczty elektronicznej), aby mogli polecić konferencję, a nawet delegować pracownika na taki wyjazd. Ważnym czynnikiem przy wyborze konferencji EIW było wcześniejsze spotkanie z przedstawicielami uczelni zapraszającej na uczelni przyszłego delegata. Podobne wyniki w zakresie preferowanych metod komunikacji (koncentrujących się na sprzedaży osobistej, marketingu bezpośrednim i public relations) można zauważyć $\mathrm{w}$ badaniach przeprowadzonych z udziałem uczestników innych spotkań konferencyjnych (EMS, 2017; Nummela, 2017). Ten sposób komunikacji z uczestnikami wydarzenia jest charakterystyczny dla rynków B2B (EIU, 2007; Gilliland, Johnston, 1997).

Autorzy artykułu zidentyfikowali kluczowe czynniki motywujące do udziału w spotkaniach konferencyjnych typu EIW. Czynniki te należą do grupy oficjalnych motywów związanych z celami zawodowymi, zdobywaniem wiedzy, nawiązywaniem nowych relacji zawodowych itp. Przegląd wyników innych konferencji pozwala zauważyć, że motywacje te dotyczą również uczestników innych spotkań biznesowych (Anahitaet, 2011; Jung, Tanford, 2017; Oppermann, 1995).

Ciekawe wyniki badań uzyskano także po dokonaniu analizy głównych czynników wyboru spotkania konferencyjnego i poziomu ich realizacji. $\mathrm{W}$ opinii uczestników EIW w Kownie najważniejsze czynniki to "nowość uczelni przyjmującej” i „dostępność informacji”. Uczelnia wyższa jest traktowana zarówno jako miejsce konferencji, jak i jednostka naukowa (ośrodek akademicki). Może to świadczyć o dużym zaangażowaniu uczestników spotkania w proces przygotowania się do podróży na konferencję, a także o stworzeniu produktu systemowego, jakim jest konferencja (składa się z wielu usług, które kupują uczestnicy).

Wszelkie spotkania biznesowe stają się wspólnym doświadczeniem uczestników, a także organizatorów spotkań. W tym kontekście konferencja jest atrakcyjnym produktem współczesnej gospodarki opartej na doświadczeniach (Chang, 2018; Stasiak, 2013). Konferencja jako produkt zaspokaja wiele różnych potrzeb jej uczestników. Jest to zatem przykład nowoczesnego produktu systemowego (Niemczyk, 2014; Olearnik, 2016). W teorii zarządzania usługami stwierdzono, iż zadowolenie z usługi może rozwinąć się w lojalność klientów (Hallowell, 1996). Można zatem spodziewać się tego, iż osoby biorące udział $\mathrm{w}$ konferencjach naukowych zostaną w przyszłości uczestnikami innych form turystyki i będą pozytywnie wpływać na rozwój różnych sektorów gospodarki danych destynacji.

\section{WNIOSKI}

Współczesne konferencje są złożonymi produktami systemowymi na rozwijającym się rynku turystycznym. Sukces podmiotów zaangażowanych w organizację i obsługę takich spotkań biznesowych można opisać jako proces identyfikacji i spełniania oczekiwań uczestników (delegatów). Koncepcja konferencji obejmuje różne formy spotkań, które można wyodrębnić według 
różnych kryteriów (np. znaczenie spotkań dla destynacji, skala internacjonalizacji wydarzenia, siła wpływu na rozwój miejsca docelowego, sposoby finansowania organizacji wydarzenia, jak i udziału uczestników). Autorzy stwierdzili, że konferencje EIW, będące interesującym przykładem współczesnych spotkań konferencyjnych, mogą być rozpatrywane jako przykład produktów systemowych. Te międzynarodowe konferencje odbywają się corocznie (powtarzalnie) w wielu krajach i są finansowane ze środków Unii Europejskiej. Aby zidentyfikować czynniki sukcesu tych spotkań jako systemowych produktów turystycznych, autorzy skupili się na opiniach zagranicznych gości uczestniczących w EIW w Kownie na Litwie.

Analiza kalendarza konferencji EIW w ciągu roku pozwoliła zauważyć, że większość wydarzeń odbywa się w kwietniu i maju. Można przypuszczać, że zorganizowanie takiej konferencji $w$ innych miesiącach $w$ ciągu roku pomoże organizatorom uniknąć dużej konkurencji i wzbudzić większe zainteresowanie uczestników.

Ważnym elementem sukcesu konferencji jest właściwy proces komunikacji (odpowiednio zainicjowany wcześniej, aby planiści podejmowali decyzje w terminie przewidzianym $w$ ich organizacjach) przy użyciu jej odpowiednich form. Komunikacja opiera się na kontakcie podczas innych wydarzeń oraz na dotarciu do decydentów (marketing bezpośredni) w instytucjach, z których mają pochodzić uczestnicy.

Treść materiałów promocyjnych, programów, zaproszeń powinna odnosić się do oficjalnych motywacji związanych z celami zawodowymi, zdobywaniem wiedzy oraz nawiązywaniem nowych relacji zawodowych. Ważnym elementem komunikacji jest prezentacja „wiadomości o miejscu odbywania się konferencji”, a także różnych aspektów „nowości głównego organizatora".

Z uwagi na fakt, że zarówno przełożeni, jak i przyszli uczestnicy decydują o udziale w konferencjach, konieczne jest bardzo dobre przygotowanie informacji o wydarzeniu, mieście, miejscu docelowym (w kilku językach), w tym na temat: dostępności komunikacyjnej, zakwaterowania, ogólnego programu i później szczegółowych wydarzeń. Informacje te mogą przybrać formę rozbudowanej strony internetowej wydarzenia, ale także aplikacji mobilnej.

Ważnym czynnikiem warunkującym sukces konferencji jest również organizacja programu wydarzeń towarzyszących, w szczególności zwiedzania miejsca docelowego i okolicy. Uczestnikami międzynarodowych konferencji są osoby z zagranicy, bardzo zainteresowane nawiązaniem profesjonalnych kontaktów, promocją własnej instytucji, ale także poznaniem miasta i kraju, do którego przyjechały. Dlatego szukają i oczekują od organizatorów konferencji zapewnienia usług, które zaspokoją te potrzeby. Uczestnicy sami docierają do centrów handlowych. Informacje o nich w materiałach promocyjnych nie są konieczne, ale mogą uatrakcyjnić pobyt gości w mieście i być formą spędzania czasu wolnego od zajęć konferencyjnych.

Autorzy skoncentrowali się na analizie wybranych determinant atrakcyjności spotkań konferencyjnych. Mają też świadomość ograniczeń związanych z tymi badaniami i wnioskowaniem wynikającym z analizy zastosowanych w nich kryteriów oraz pewnej dynamiki zmian oczekiwań uczestników spotkań konferencyjnych. Artykuł może być przykładem metodyki badań naukowych spotkań konferencyjnych, które w warunkach zmian gospodarczych w Europie są interesującymi produktami zarówno przedsiębiorstw, jak i instytucji publicznych. Dalsze udoskonalanie czynników sukcesu, ich obserwacja oraz identyfikacja warunków rozwoju takich produktów wymagają badań różnych rodzajów konferencji przeprowadzonych $\mathrm{w}$ wielu krajach. Wskazane w artykule czynniki warunkujące sukces spotkań EIW mogą być wykorzystane przez organizatorów innych konferencji naukowych, a także organizacji turystycznych, aby zwiększyć atrakcyjność ich ofert i lepiej zorganizować różne usługi zawarte $\mathrm{w}$ takich produktach systemowych jak konferencje międzynarodowe.

\section{BIBLIOGRAFIA}

Agha, N. (2011). The economic impact of stadiums and teams. Journal of Sports Economics, 14 (3), 227-252. DOI: https:// doi.org/10.1177/1527002511422939

Ayaz, N., Şamata, N. (2017). Integration of congress tourism to the cultural tourism destinations as an economic product. Journal of Tourism and Hospitality Management, 5 (1), 53-61. DOI: https:// doi.org/10.15640/jthm.v5n1a6

Berbeka, J., Borodako, K., Niemczyk, A., Seweryn, R. (2014). Influence of the meetings industry on the economy of Kraków. Kraków: Foundation of the Cracow University of Economics.

Borodako, K., Berbeka, J., Rudnicki, M. (2014). The potential of local KIBS Companies as a determinant of tourism development in Krakow. Tourism Economics, 20 (6), 1337-1348. DOI: https:// doi.org/10.5367/te.2013.0351

Borodako, K., Kožić, I. (2016). Cooperation patterns in the tourism business: The case of Poland. Prague Economic Papers, 25 (2), 160-174. DOI: https://doi.org/10.18267/j.pep.552

Breiter, D., Milman, A. (2006). Attendees' needs and service priorities in a large convention center: Application of the importance-performance theory. Tourism Management, 27 (6), 1364-1370. DOI: https://doi.org/10.1016/j.tourman.2005.09.008

Chang, S. (2018). Experience economy in the hospitality and tourism context. Tourism Management Perspectives, 27, 83-90. DOI: https://doi.org/10.1016/j.tmp.2018.05.001

Cieślikowski, K. (2014). Rynek turystyki konferencyjnej. Tom I: Podstawy teoretyczne. Funkcjonowanie i rozwój na świecie. Katowice: Wydawnictwo Akademii Wychowania Fizycznego.

Cieślikowski, K. (2015). Business tourism as innovative product for destinations. Innovative (Eco-) Technology, Entrepreneurship and Regional Development, 26-33.

Cieślikowski, K., Brusokas, A. (2017). Determinants of effective management in sport with the use of large sport arenas in 
selected cities. European Journal of Service Management, 21, 5-10. DOI: https://doi.org/10.18276/ejsm.2017.21-01

Cieślikowski, K., Brusokas, A. (2019). Meetings Industry in Kaunas. Report. Katowice: Wydawnictwo Akademii Wychowania Fizycznego.

Crouch, G.I., Louviere, J.J. (2004). The determinants of convention site selection: A logistic choice model from experimental data. Journal of Travel Research, 43 (2), 118-130. DOI: https:// doi.org/10.1177/0047287504268233

Crouch, G.I., Ritchie, J.R. (1997). Convention site selection research. Journal of Convention \& Exhibition Management, 1 (1), 49-69. DOI: https://doi.org/10.1300/j143v01n01_05

Davidson, R., Cope, B. (2003). Business travel: Conferences, incentive travel, exhibitions, corporate hospitality, and corporate travel. Nowy Jork: Pearson Education, Financial Times.

Dwyer, L., Forsyth, P. (1997). Impacts and benefits of MICE tourism: A framework for analysis. Tourism Economics, 3 (1), 21-38. DOI: https://doi.org/10.1177/135481669700300102

Dwyer, L., Forsyth, P., Spurr, R. (2004). Evaluating tourism's economic effects: New and old approaches. Tourism Management, $25,307-317$.

ECEC (2014). The Erasmus impact study. Effects of mobility on the skills and employability of students and the internationalization of higher education institutions. Bruksela: The European Commission Educational and Culture.

EIC (2018). Economic significance of meetings to the US economy. Nowy Jork: Events Industry Council and Oxford Economics.

EIU (2007). Megatrends in B2B marketing. Londyn: The Economist Intelligence Unit.

EMS (2017). Feedback from conference participants. (Report). Dublin: European Meteorological Society.

Fenich, G.C. (2001). Towards a conceptual framework for assessing community attractiveness of conventions. Journal of Convention and Exhibition Management, 3 (1), 45-64. DOI: https:// doi.org/10.1300/J143v03n01_04

Gilliland, D.I., Johnston, W.J. (1997). Toward a model of business-to-business marketing communications effects. Industrial Marketing Management, 26 (1), 15-29. DOI: https://doi.org/10.1016/ s0019-8501(96)00032-6

Gugg, A., Hank-Haase, G. (1995). Die wirtschaftliche Bedeutung des Tagungs- und Kongressreiseverkehrs in Deutschland. Frankfurt: GHH Consult GmbH.

Hallowell, R. (1996). The relationship of customer satisfaction, customer loyalty, and profitability: An empirical study. International Journal of Service Industry Management, 7 (4), 27-42. DOI: https://doi.org/10.1108/09564239610129931

ICCA (2007).The international Association Meetings Market 2006: ICCA Statistics Report. Amsterdam: International Congress and Convention Association.

Jung, S., Tanford, S. (2017). What contributes to convention attendee satisfaction and loyalty? A meta-analysis. Journal of Convention \& Event Tourism, 18 (2), 118-134. DOI: https://doi.org/ 10.1080/15470148.2017.1290565

Komisja Europejska (2018). What is Erasmus? Pobrane z: http:// ec.europa.eu/programmes/erasmus-plus/about_en (17.08.2018).

Lemanowicz, M., Puciata, E. (2010). Czynniki warunkujące sukces produktów turystycznych województwa małopolskiego. Acta Scientiarum Polonorum. Oeconomia, 9 (4), 255-265.

Malaval, P., Bénaroya, C., Digout, J., Szapiro, G. (2013). Business to business marketing from industrial to business marketing: Adaptation from $5^{\text {th }}$ French edition. Bruxelles: De Boeck.

Malekmohammadi, A., Mohamed B., Ekiz, E.H. (2011). An analysis of conference attendee motivations: Case of international conference attendees in Singapore. Journal of Travel and Tourism Research, 11 (1), 50-64.
NBTC (2015). Business meetings in Holland. An analysis of the impact of the industry. Amsterdam: NBTC Holland Marketing.

Niemczyk, A. (2014). Produkty systemowe na rynku turystycznym. Ekonomiczne Problemy Turystyki, 1 (25), 79-99.

Nummela, C. (2017). Delegate survey 2016 (Rep.). Helsinki: Finland Convention Bureau.

Olearnik, J. (2016). Contemporary marketing in tourist industry. Ekonomiczne Problemy Turystyki, 33, 9-19. DOI: https:// doi.org/10.18276/ept.2016.1.33-01

Oppermann, M. (1995). Professional conference attendees' and non-attendees' participation decision factors. The Society of Travel and Tourism Educators Annual Conference, 7 (1), 25-37.

Oppermann, M. (1996). Convention destination images: Analysis of association meeting planners perceptions. Tourism Management, 17 (3), 175-182. DOI: https://doi.org/10.1016/0261-5177(96)00004-0

Pal, D., Joshi, A., Kale, S., Chandel, S. (2015). Likert scale: Explored and explained. British Journal of Applied Science \& Technology, 7 (4), 396-403. DOI: https://doi.org/10.9734/bjast/2015/14975

Rogers, T., Davidson, R. (2016). Marketing destinations and venues for conferences, conventions and business events. Abingdon, Oxon: Routledge.

Sidorkiewicz, M. (2014). Specyfika organizowania konferencji i kongresów naukowych. W: K. Celuch (red.), Zarzadzanie i organizacja przemysłu spotkań w Polsce (s. 91-103). Warszawa: Szkoła Główna Turystyki i Rekreacji.

Smith, J. (2018). Who can take part? Pobrane z: http://ec.europa. eu/programmes/erasmus-plus/about/who-can-take-part_en (20.08.2018).

Staff weeks search (2018). Pobrane z: http://staffmobility.eu/staff-week-search (13.08.2019).

Stasiak, A. (2013). Tourist product in experience economy. Turyzm/Tourism, 23 (1), 27-36. DOI: https://doi.org/10.2478/ tour-2013-0003

Swarbrooke, J., Horner, S. (2011). Business travel and tourism. Nowy Jork: Routledge. DOI: https://doi.org/10.4324/9780080490601

UIA (2018). International meeting statistics for the year 2017. Report. Bruksela: Union of International Associations.

UN WTO (2010). The international recommendations for tourism statistics 2008. Nowy Jork: UN WTO Publishing.

UN WTO (2014). Global report on the meetings industry. Madryt: World Tourism Organization.

Weber, K., Chon, K. (2009). Convention tourism: International research and industry perspectives. Nowy Jork: Routledge.

WTTC (2018). Travel and tourism economic impact 2018 (Report). Londyn: World Travel \& Tourism Council.

Zeithaml, V.A., Parasuraman, A., Berry, L.L. (1990). Delivering quality service: Balancing customer perceptions and expectations. Nowy Jork: The Free Press.

Zhang, H.Q., Leung, V., Qu, H. (2007). A refined model of factors affecting convention participation decision-making. Tourism Management, 28 (4), 1123-1127. DOI: https://doi.org/10.1016/j. tourman.2006.07.008

Żabiński, L. (2012). Marketing produktów systemowych. Warszawa: Polskie Wydawnictwo Ekonomiczne.

Żemła, M. (2010). Destination brand licensing. W: M. Kozak, J. Gnoth, L. Andreu (red.), Advances in tourism destination marketing: Managing networks (s. 110-120). Londyn: Routledge.

Artykuł wpłyną: 28 sierpnia $2019 \mathrm{r}$. Zaakceptowano do druku: 27 marca $2020 \mathrm{r}$. 